\title{
CHRISTIAN SOCIAL ETHICS IN THE BUSINESS ENVIRONMENT
}

\author{
Jekaterina Kuzmina \\ BA School of Business and Finance, Latvia, jekaterina_kuzmina@yahoo.de \\ cross $^{\text {ref }}$ http://dx.doi.org/10.5755/j01.em.17.2.2201
}

\begin{abstract}
Global economic and financial crisis has forced politicians, economists and ordinary people irrespective of their political, cultural, and religious affiliation to think about values and realization of these values in the market economy. The need and desire for a renaissance of social market economy is particularly relevant in regard to the latest financial crisis and its consequence. So that the topicality of this problem encouraged to formulate the following goal of the paper: based on the interdisciplinary literature study to find an opportunity of updating the concept of social ethics and to create a model, which includes European Christian cultural values, but at the same time meets the requirements of the modern business environment. Based on the analysis the author provides the theoretical model including cooperation opportunities inside the business organization. Consequently, both Christian social ethics`concept and socio-political issues are used, providing the possibility for interdisciplinary exchange and dialogue.

Keywords: Christian social ethics, St. Gallen integrative economic ethics.

JEL Classification: Z12, M59.
\end{abstract}

\section{Introduction}

The credit crunch that had first manifested itself in August 2007 was speeding up during the summer, though everybody outside and inside mainstream finance in the US and Europe was oblivious to this threatening tidal event. Despite attempts to find other scapegoats, most economists agree that the blame for the global financial crisis primary lies within the banks and other financial institutions. The financial disaster started with the asset bubbles created through extreme and irresponsible lending that unavoidably had to explode. But this was a crisis not just of financial assets and financial institutions but also of confidence because the problems in the political and economical system had been greatly magnified. So that the latest global economic and financial crisis has forced politicians, economists and ordinary to think about values and their realization in the market economy. While the idea of social market economy is not innovative, and Christian social ethics within several centuries have been discussing this topic, willing to solve the dilemma between capital and moral (as for example by Furger, 1992). The topicality of the issue forces to formulate the following goal of the paper: based on the interdisciplinary literature study to find an opportunity of updating the concept of Christian ethics and to create a model, which includes European Christian cultural values, but at the same time meets the requirements of the modern business environment.

In order to achieve the goal the author clarifies the scope of business views on ethical issues based on the St. Gallen theoretical concept of integrative economic ethics created by Peter Ulrich. In the second step the author explores the social doctrine of the Christian Church based on the Roman Catholic Church's social Encyclicals. The third and the final step is finding the connection points of the both concepts that could be used as the basis for joint dialogue in order to expand the St. Gallen's concept. It is worth considering that despite some different argumentation samples, as well as the contradictory positions in terms of success, life values, norms and morale schemes, both concepts - Roman Catholic Church's social Encyclicals as an example of Christian social ethics and St. Gallen theoretical concept of integrative economic ethics - provide similar results, and orientations for the individuals. So that there is a common grounds between the two concepts for interdisciplinary discussion and a kind of "joint venture" that could be used in practice in the business environment. Based on the analysis the author provides the theoretical model including cooperation opportunities on the three specific levels inside the business organization. The theoretical model uses both concepts on three levels in the organization: macro level, meso level and micro level.

\section{St. Gallen Concept of Integrative Economic Ethics}

The approach of the integrative economic ethics was conceptualizes in St. Gallen by P. Ulrich (1997) and the author starts with critical reflection on the normative foundations of the economic thinking. It is important as normative claims are already hidden within the economic logic of the market economy and allows reconstructing this principle as an ethically valuable socio-economic rationality. So that integrative economic ethics is willing to integrate ethical reason into the idea of economic rationality and becomes a fundamental or a comprehensive reflection on the normative preconditions of ethically important and life- 
conductive ways of rational economic value-creation process. The concept of integrative economic ethics tackles three main tasks. Short introduction in these tasks provides to better understanding of the concept described above. The first task is the critique of pure economic reason and of the economism. The second is the clarification of an ethical integrated idea of socio-economic rationality and of the basic dimension of a life-conductive economy. The third and the last task is the determination of the "loci" of moral reasoning and responsibility with respect to economic behaviour and policies in a well-ordered society of free citizens. This means that the ethical concept turns out to be a piece of political ethics. So that the approach developed by P. Ulrich is an attempt of comprehensive ethical re-orientation of economic reasoning on the basis of philosophical ethics and political philosophy.

P. Ulrich outlines in his concept a model of society as part of business ethics reflection and is proposing a "third way" between the conventional alternatives like economic liberalism and more regulation like social statism (Ulrich, 2005). The foundation of all the efforts is based on the role of economic citizen in the integrative social ethics he is both bourgeois and citoyen. That means he is the owner of productivity factors and also involved in the life of society solving such questions as responsibility and solidarity. In such a society the probability that the economy serves the people and not vice versa is the highest. These ideas (Ulrich, 2005) can be presented as theoretical model as following in the Figure 1.

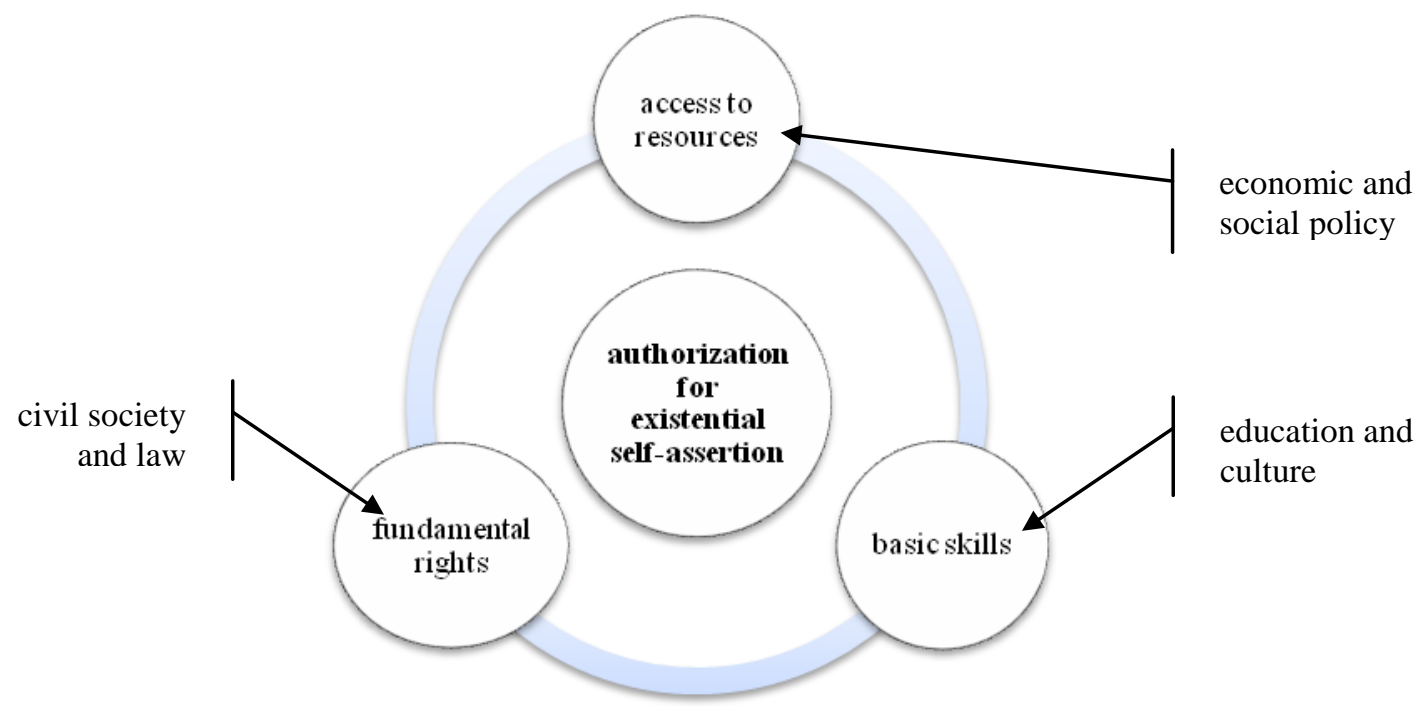

Figure 1. Civil society as "third way"

In order to provide evidence that the business ethics postulates are not utopian Ulrich distinguishes business ethics topology (Ulrich, 2001).

\begin{tabular}{l|l|}
\hline domain of ethic rules: & \\
\hline - ordolib eralism as deliberative governance & \\
\hline domain of economic citizen ethics: & domain of business ethics: \\
\hline - reflecting consumer & - corporate resposiblity \\
\hline - critical investors & - charitable business ethics \\
\hline - organizational citizen & \\
\hline - responsible citizens & \\
\hline
\end{tabular}

Figure 2. Ethics topology

The practice of life-serving economic activity is based on three different levels (follow Figure 2 above), which should be explained in details: the holders of morality are both an individual citizen as an economic actor (domain of economic citizen ethics), and also the companies and organizations as collective leaders (domain of business ethics). Both the holders need a kind of normative umbrella - nationally and 
globally determined market order (domain of ethic rules). The aim of these considerations is a harmonious balance between individual ethics and institutional ethics, between self-claims of any economic agent and the necessary of moral environment.

It is worth considering that the St. Gallen concept of integrative economic ethics is not an ideal one, as this approach does not take into account the necessity of maintenance of economic interests. St. Galler approach is based on philosophical and critical analysis, while knowledge of cybernetics, game theory and institutional economics was not incorporated. P. Ulrich builds his theory on the moral characteristics of each economic actor while the role of normative regulatory authority is neglected, so that the successful implementation of the approach is difficult. Further critics of the St.Gallen approach can be found by Steinmann (2004), Leisinger (2004) and Christ (2006). The kind of normative regulatory authority can be represented by Ethics Institutes and different Associations, but also by church due to the fact that even though the church is divided from the state, but according to the latest surveys most the Europeans consider themselves as bearers of Christian religious and cultural heritage.

\section{Roman Catholic Church's Social Encyclicals}

According to the Catholic Doctrine the church is a part of the divine plan of salvation. It is supposed to realize its mission both in material and spiritual categories. It should be considered that theological-ethical reflection is tied to the divine revelation and the statements of scripture (both Old and New Testament). Nevertheless the long intellectual history and solid foundation, the confrontation with social questions began in the first half of the 19th century. So that the modern social teaching begins with the publication of encyclical Rerum Novarum by Pope Leo XIII, in which he speaks about the negative excesses of capitalism in the modern industrial societies. The Catholic Church has been trying to ensure that this document is considered both as economic and religious Magna Carta that has been developed and updated later on, establishing a hundred-year tradition of church`s social encyclicals (follow Figure 3). The following part is going to summarize the development of the social teaching of Catholic Church and provide main aspects of the documents.

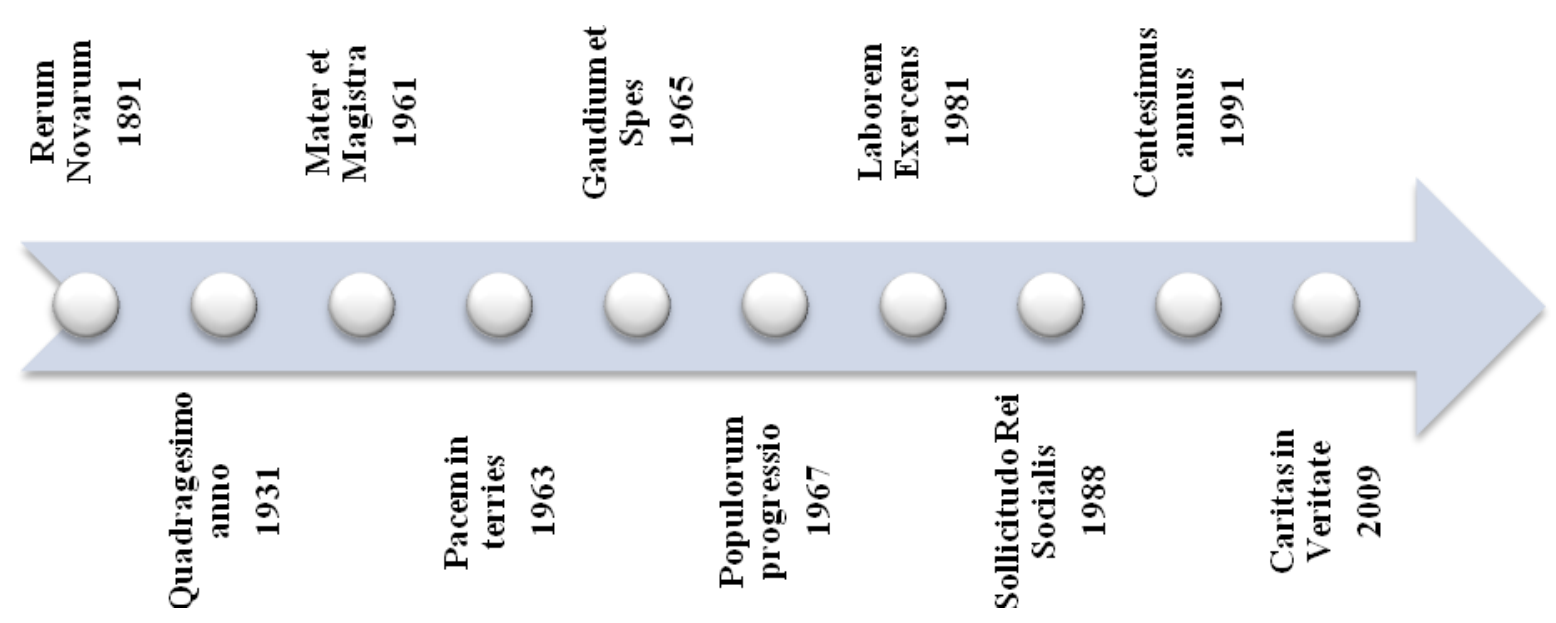

Figure 3. Hundred-year tradition of church`s social encyclicals

Rerum Novarum (Pope Leo XIII, 1891) - the opening words and the title of the Encyclical issued by Leo XIII is the "Condition of Labour". The Encyclical follows the lines of the traditional teaching concerning such aspects as the rights and duties of property and the relations between employer and employee, it also applies the old doctrines specifically to modern conditions. It develops the idea that the true remedy can be found in the combined action of the Church, the State, the employer and the employed. It is explained that the Church is properly interested in the social question because of its religious and moral aspects; the State has the right and the duty of intervention on behalf of justice and individual and social well-being; while the employers and workers should organize into both mixed and separate associations for mutual protection and for self protection. Quadragesimo anno (Pope Pius XI, 1931) was issued on social issues in commemoration of Leo XIII's first modern social encyclical. Confronting severe world economic conditions, the message included a censure of the capitalist order and a recommendation to move toward a 
more corporatist system. At the same time, the letter also included a reiteration of Leo's condemnation of socialism and a strong statement against excessive extension of state power. Mater et Magistra (Pope John XXIII, 1961) is the encyclical written on the topic of Christianity and Social Progress, and it is referring to the role of the church, describing a necessity to work towards authentic community in order to promote human dignity. Pacem in terries (Pope John XXIII, 1963) was the first encyclical that the Pope did not address to the Catholic faithful only, but also to all men of good will, highlighting the importance of respect of human rights as an essential consequence of the Christian understanding of men. Gaudium et Spes (Pope Paul VI, 1965) is one of the four Apostolic Constitutions resulting from the Second Vatican Council. The document is an overview of the Catholic Church's teachings about humanity's relationship to society, especially in reference to economics, poverty, social justice, culture, science, technology and ecumenism. Populorum progressio (Pope Paul VI, 1967) was devoted to the topic of the development of people and that the economy of the world should serve mankind and not just the few. It touches on a variety of principles of Catholic social teaching, as for example the right to a just wage; the right to security of employment; the right to fair and reasonable working conditions; the right to join a union; and the universal destination of resources and goods. It had become traditional for Popes to publish new writings on social issues on ten-year anniversaries of Rerum Novarum, in order to keep the teachings relevant to the current times. Laborem Exercens (Pope John Paul II, 1981) was written in respect to the $90^{\text {th }}$ anniversary, and makes reference to Rerum Novarum. The main ideas of the document could be summarized as following: increased use of technology would bring changes comparable to the industrial revolution of the previous century. The Pope noted that some resources, particularly oil, were becoming scarce. Also, the need to protect the environment was becoming apparent. People in the developing world wanted to be more involved in the global economy. John Paul welcomed this trend, but feared it would bring unemployment for many skilled workers as work was distributed more widely. In Sollicitudo Rei Socialis (Pope John Paul II, 1988) the global development and its ethical and moral dimensions are discussed. The Pope builds on Pope Paul VI's work, and after surveying the state of poor countries, he considers the confrontation between the two global blocs. He then points to the structures of $\sin$ as obstacles to development and calls for conversion towards solidarity. Centesimus annus (Pope John Paul II, 1991) was written during the last days of the Cold War, was examining contemporaneous political and economic issues. The encyclical expounds on issues of social and economic justice, including a defense of private property rights and the right to form private associations, like labor unions. The reoccurring themes of social and economic justice mentioned in the document articulate foundational beliefs in the social teaching of the Catholic Church. Throughout the encyclical the Pope calls on the State to be the agent of justice for the poor and to protect human rights of all its citizens. Caritas in Veritate (Pope Benedict XVI, 2009) - the encyclical is concerned with the problems of global development and progress towards the common good, arguing that both Love and Truth are essential elements of an effective response. The work is addressed to the global society and contains detailed reflection on economic and social issues and problems. The Pope points out that the Church does not offer specific technical solutions, but rather moral principles to inform the building of such solutions. The economic themes include an attack on free market fundamentalism, though a simplistic polarization of the free market model versus interventionist big government solutions is rejected. There is importance of the need for the actions of all economic actors to be informed by ethics as well as the profit motive.

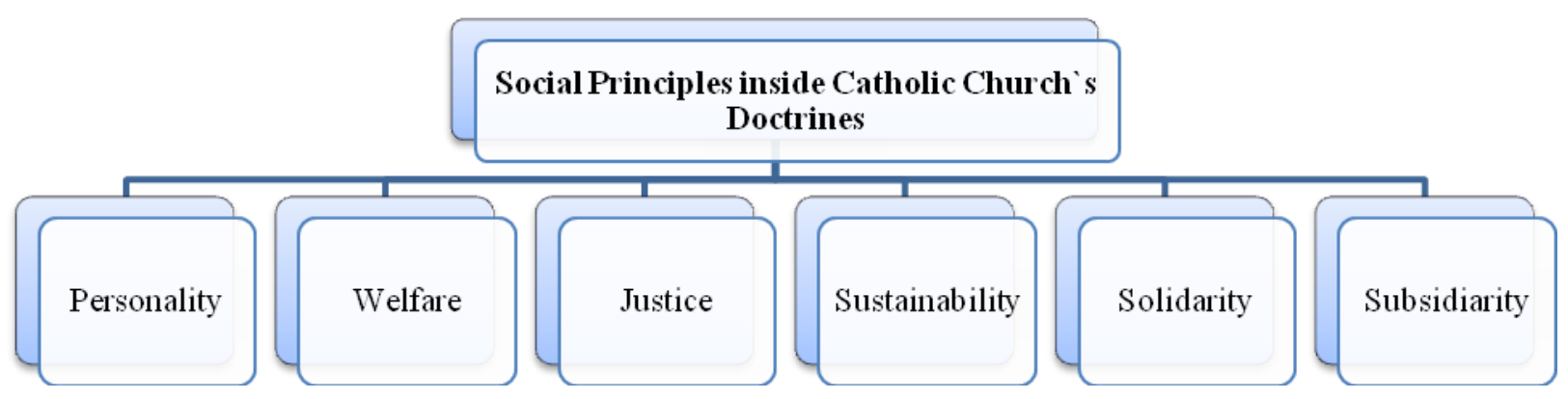

Figure 4. Social Principles

Based on the chronological presentation of the social doctrines issued by the Catholic Church the focus should be shifted to the principles of social conduct. These social principles are the result of the efforts 
incurred at different times, nevertheless there is a possibility of insights` and doctrines`systematization in order to provide some proves of their timelessness and connection to contemporary historical periods and political contexts. The encyclicals provides basis for the summary of the following social principles (follow Figure 4 above) explained below.

According to the Catholic Church`s Doctrines the man is incomparable and unique in every subject, and a kind of special dignity belongs to him. On the other hand, the man is a part of community, who is asking for respect and love, while these aspects should fit into social order. This dual anthropological determination of man as individual and social being finds its spirit in the two mutually interrelated principles of personality and welfare. Another basic question for a good and peaceful coexistence within a social community is that of justice. Throughout the theological history different concepts of fair distribution of goods were developed and debated. The significant question about the relation between individuals and group as well as necessary socio-economic structures that will meet the ideal is to be considered in relation to the time axe. The goal of intergenerational equity and the corresponding responsibility of natural resources is determined in the principle of sustainability. The last pair of terms has a special place regarding their historical background. The question of solidarity was particularly virulent by the shift to a modern labor and industrialized society, while the new forms of organization and social unity were necessary. As a counterpoint the principle of subsidiary was formulated, and especially appropriate in response to the totalitarian forms of government in order to protect the personal responsibility of individuals.

Summarizing one can formulate the following duties and social profile of theological ethics: it as an ethical reflection of all social processes, institutions and structures is accompanying all the questioning circumstances, it seeks to understand them, it examines implications, opportunities and obstacles for a wellformed co-existence of humans. From their own perspective theological ethics designs normative orientations and it tries to implement them into a polyphonic discourse of societal goals and means, while developing argumentative structures.

\section{Theoretical Interdisciplinary Concept}

Despite the different patterns of argumentation and contrary position in terms of the highest instance of moral system of values, norms and expectations both the integrative business ethics and the Catholic social teaching are reaching to similar results and orientations. So that there is a basis for a fruitful further dialog and cooperation on the field of business ethics.

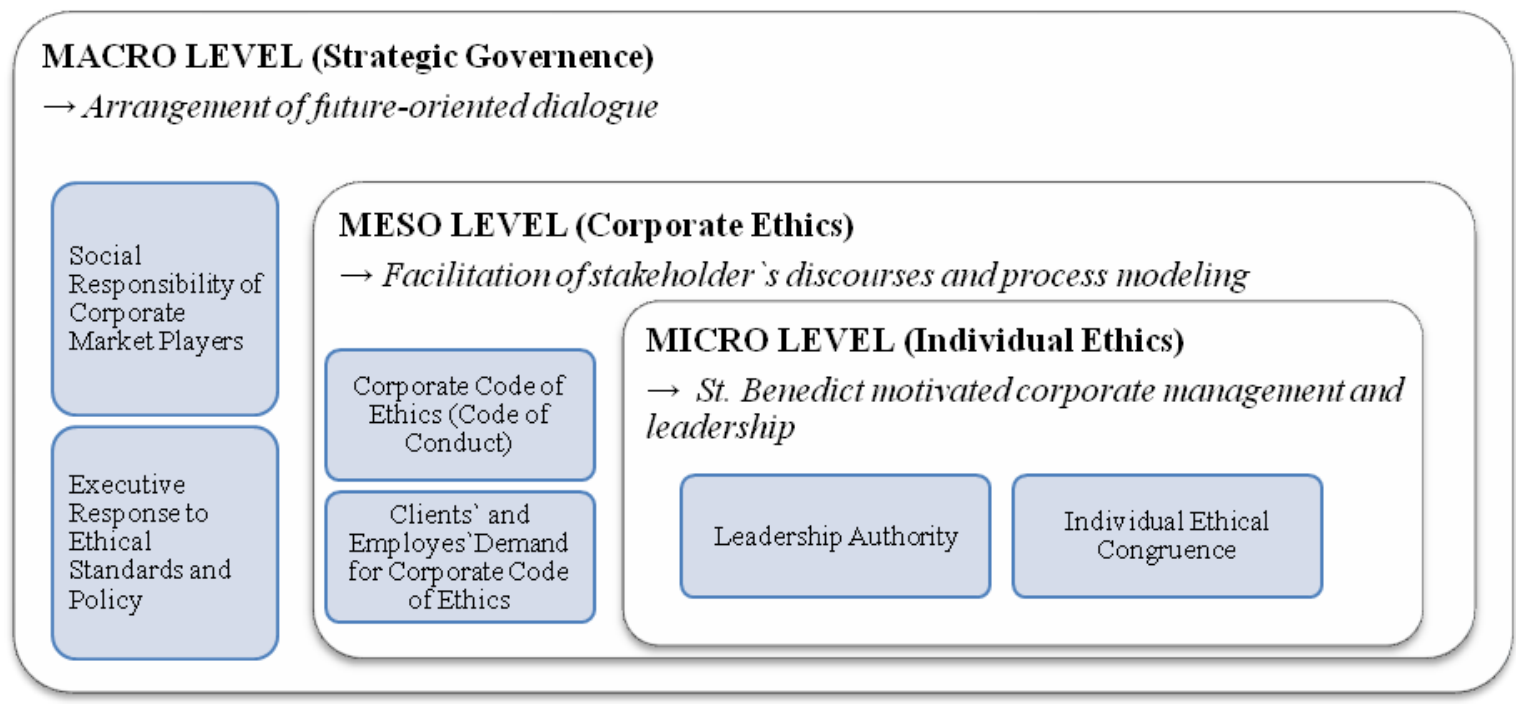

Figure 5. Interdisciplinary concept

The last part of the current paper is devoted to the discussion of dialog and cooperation possibilities. So that three specific areas of action are going to be presented. It is important to underline that each area, where cooperation is possible, is situated on a different recursion level inside the economic organizations (micro level, meso level and macro level). As a result of these considerations a profile of a Christian business ethics can be developed and described. The concept is based on doctrines and tradition, in the economic and social policy issues it stays on the pulse of the signs of the time and it also remains in the interdisciplinary 
exchange with other concepts. The Figure 5 above shows a theoretical interdisciplinary model of Christian business ethics.

On the micro level it is possible to consider St. Benedict motivated corporate management and leadership principles, as the church has been acquiring skills in the proper and humane management of employees, groups or organizations. Especially the monastic communities have been developing rules for a well-ordered coexistence, describing the necessary qualities and attitudes of a leader. These insights and wisdoms were gained over generations and many of them do not lose their importance today, so that a transfer of the rules of St. Benedict in the commercial world of managers and executives is possible. The kind of transfer would lead to the following management principles as both-side attention inside the organization and permanent learning from each other; the role of manager defined as a culture of service; appreciation of individual diversity. Further discussion can be found by Grün (2004) and Bilgri \& Stadler (2004).

On the meso level the aspect of facilitation of stakeholder`s discourses and process modeling can be discussed. These considerations are based on the idea, that the ethical quality of a company is measured not only by its voluntary service, social engagement, or good relationships between management and employees, but also by its moral commitment to customers, suppliers, other stakeholders and society and environment. Further discussion can be found by Ulrich (2005) and Kleinfeld (2004).

On the macro level one can consider the fact that the church can and should make use of the orientation vacuum during the period of volatile financial markets and economic downturn, and engage itself with an ecumenical effort in initiatives and projects. The church (regardless the confession) could take the role the agent responsible for common good in order to create discourse for further exchange and contribution of new impulses. Therefore, the churches (along with the Christian organizations) in accordance with the principle of subsidiary should not be engaged in the sense of making policy, but they can fulfill their tasks by providing methodological competence and supporting clarity of content, in order to ensure a new style human politics. Further discussion can be found by Heimbach-Steins (2001).

\section{Conclusions}

The main goal of the current paper was to determine a possibility of successful interdisciplinary exchange between the integrative business ethics and the Catholic social ethics. Critical analysis has shown that a forward-looking dialogue is possible. In the current part main results of the study should be summarized.

1. Although both approaches differ from each other in terms of their definition of moral principle, there are some intersections at the level of substantive statements - both approaches reflect their view of a man as a representative of a high ideal. These intersections provide a basis for possible transfers between both disciplines.

2. Both concepts of social ethics and Catholic social teaching have been uniting theoretical and practical skills, providing critical analysis and constructive participation in social function.

3. The Catholic social ethics that is based on already well-developed resources could have more influence on spectrum of business ethics models and consulting services. In order to insure this possibility two impulses from the concept of integrative economic ethics can be derived:

a. Increased consideration of companies and entrepreneurs as the real backbone of the economy (through the reception of the figure of good corporate citizens).

b. Intensive participation in the discussion about the ways and means of good, justified and lasting economic activity and contribution to these processes.

4. An interdisciplinary comparison of integrative economic ethics and Catholic social ethics allows coming to the conclusion that further dialog could be based on the following approach: integration criticism - stimulation. Both positions are consistent in their self-understanding not to be a partdiscipline to complement other field of studies, but they are representing the ethical code for men in the different aspects of life, while dialog is necessary and welcomed from both parts (integration). From the side of Catholic social doctrine one can notify (criticism) that the model developed by Peter Ulrich is far away of any transcendent reference, which is an important intellectual argumentative and deprived resource. So that social principles developed through the centuries could be a stimulating impulse (stimulation) for the concept of good co-existence of men. 


\section{References}

1. Bilgri, A. / Stadler, K. (2004) Finde das rechte Maß. Regeln aus dem Kloster Andechs für Arbeit und Leben. München/Zürich: Piper.

2. Christ, Ph. (2006). Organisation der Verantwortung der Organisation. Grundlagen, Leitideen und Leitlinien kybernet(h)ischen Managements. Bern/Stuttgart/Wien: Haupt.

3. Furger, F. (1992). Moral oder Kapital? Zürich: Benzinger.

4. Grün, A. (2001). Menschen führen, Leben wecken. Münsterschwarzach: Vier Türme.

5. Heimbach-Steins, M. (2001). Einmischuung und Anwaltschaft. Für eine diakonische und prophetische Kirche. Ostfildern: Schwabenverlag.

6. Kleinfeld, A. (2004). Persona Oeconomica. Personalität als Ansatz der Unternehmensethik. Heidelberg: Physica.

7. Leisinger, K. M. (2004). Die Integrative Wirtschaftsethik. Nicht nur gut gemeint, auch gut gemacht. In Ulrich, U. / Breuer, M. (Eds.), Was bewegt die St. Gallener Wirtschaftsethik? 14 Einschätzungen von außen. (pp. 24-25). St. Gallen.

8. Pope Leo XIII (1891). Rerum Novarum. Retrieved from

http://www.vatican.va/holy_father/leo_xiii/encyclicals/documents/hf_1-xiii_enc_15051891_rerumnovarum_en.html

9. Pope Pius XI (1931). Quadragesimo anno. Retrieved from http://www.vatican.va/holy_father/pius_xi/encyclicals/documents/hf_p-xi_enc_19310515_quadragesimoanno_en.html

10. Pope John XXIII (1961). Mater et Magistra. Retrieved from http://www.vatican.va/holy_father/john_xxiii/encyclicals/documents/hf_j-xxiii_enc_15051961_mater_en.html

11. Pope John XXIII (1963). Pacem in terries. Retrieved from http://www.vatican.va/holy_father/john_xxiii/encyclicals/documents/hf_j-xxiii_enc_11041963_pacem_en.html

12. Pope Paul VI (1965). Gaudium et Spes. Retrieved from http://www.vatican.va/archive/hist_councils/ii_vatican_council/documents/vat-ii_cons_19651207_gaudium-etspes_en.html

13. Pope Paul VI (1967). Populorum progressio. Retrieved from http://www.vatican.va/holy_father/paul_vi/encyclicals/documents/hf_p-vi_enc_26031967_populorum_en.html

14. Pope John Paul II (1981). Laborem Exercens. Retrieved from http://www.vatican.va/holy_father/john_paul_ii/encyclicals/documents/hf_jp-ii_enc_14091981_laboremexercens_en.html

15. Pope John Paul II (1988). Sollicitudo Rei Socialis. Retrieved from http://www.vatican.va/holy_father/john_paul_ii/encyclicals/documents/hf_jp-ii_enc_30121987_sollicitudo-reisocialis_en.html

16. Pope John Paul II (1991). Centesimus annus. Retrieved from http://www.vatican.va/holy_father/john_paul_ii/encyclicals/documents/hf_jp-ii_enc_01051991_centesimusannus_en.html

17. Pope Benedict XVI (2009). Caritas in Veritate. Retrieved from http://www.vatican.va/holy_father/benedict_xvi/encyclicals/documents/hf_ben-xvi_enc_20090629_caritas-inveritate_en.html

18. Steinmann, H. (2004). Konzeption der Unternehmensethik im Test der Globalisierung. In Bausch, Th. / Böhler, D. / Rusche, Th. (Eds.), Wirtschaft und Ethik. Strategien contra Moral? (pp. 12-20). Münster: LIT.

19. Ulrich, P. (1997). Integrative Wirtschaftsethik. Grundlagen einer lebensdienlichen Oekonomie. Bern/Stuttgart/Wien: Haupt.

20. Ulrich, P. (2001). Der entzauberte Markt. Eine wirtschaftsethische Orientierung. Freiburg/Basel/Wien: Herder.

21. Ulrich, P. (2005). Zivilisierte Marktwirtschaft. Eine wirtschaftsethische Orientierung. Freiburg: Herder. 